\title{
A Prototype Study of Klana Sewandana Figure in Wayang Golek Reyog Ponorogo as a Medium of Patriotism Implementation Character
}

\author{
Sulton $^{1 *}$, Prihma Sinta Utami ${ }^{1}$, Betty Yulia Wulansari ${ }^{1}$ \\ ${ }^{1}$ Fakultas Keguruan dan Ilmu Pendidikan, Universitas Muhammadiyah Ponorogo, Ponorogo, Indonesia \\ *Corresponding author. Email: sulton@umpo.ac.id
}

\begin{abstract}
Klana Sewandana is a central figure in Reyog Ponorogo's story who is known as a powerful king with the mainstay weapon of Pecut Samandiman. This research aimed to; 1) examine the prototype forms of Klana Sewandana figure in the form of Wayang Golek Reyog Ponorogo; 2) examine the symbolic meaning of the values of Klana Sewandana figure; 3) examine the values of patriotism character in the characterization of Klana Sewandana. The method used in this research included hermeneutics and heuristics. Hermeneutics was applied to reveal the symbolic meaning of the characters of Klana Sewandana and Heuristics was used to study the development of the prototype of Klana Sewandana figure in the form of Wayang Golek and its relevance as a medium for planting the patriotism character. 1) Study of the Klana Sewandana mask prototype has unique characteristics from other Reyog Ponorogo puppet characters and the main character of Reyog Ponorogo story; 2) The symbolic meaning of the Klana Sewandana character through the application of the color and shape of the figure's body image in the puppet show Reyog Ponorogo shows a character who has a strong character; and 3) Literacy study and analysis of Reyog Ponorogo's story, Klana Sewandana illustrates the character of the love of the motherland through its leadership in the community.
\end{abstract}

Keywords: Wayang Golek, Reyog Ponorogo, Klana Sewandana figure, patriotism character

\section{INTRODUCTION}

Indonesia is a country with multicultural realities of life. One form of multicultural life is illustrated in the birth of various kinds of local arts in Indonesia itself. These local arts will become the key in the realization of national art and as a tool to strengthen patriotism and the unity of the nation's generation. One of Indonesia's local arts which is well known throughout the world and legendary is Reyog Ponorogo art originating from East Java. Reyog Ponorogo art itself is a cultural art that has been established by UNESCO (United Nations Educational Scientific and Cultural Organization) as one of the original performing arts [1]

Reyog is a performance story as well as the original art of Ponorogo, which is full of valuable values. Starting from the historical story, the existence of Reyog Ponorogo has become one of the arts and spectacle that entertained public. Socialization to the community is certainly a strategy to reintroduce the story and the character of the main characters in the story. One of the main characters in Reyog Ponorogo story in the Bantarangin version is Klana Sewandana character. This figure is a powerful king of Bantarangin with its mainstay heritage of Pecut Samandiman. In this version of the Bantarangin story, it highlights the spirit of Klana Sewandana in achieving his goals. Historically this figure was also known as a strong and charismatic king in East Java who did not attack enemies. Therefore, he was adored.

History and stories in the study of local culture such as the story of reyog figures above should still be introduced to future generations. The treasury of Indonesian culture is undoubtedly a capital to foster the character of patriotism to ward off notions that lead to negative radical actions. Nevertheless, in reality, not all people are aware of this need. Research data related to the concern and willingness of the population in preserving cultural heritage; this is reflected in one of them through the status of the visit of the population to historical heritage / cultural heritage. In the statistical data of a survey conducted by SUSENAS MSBP in 2015, it was found that only a small number of people visited historical relics / cultural heritages, only $5.39 \%$, the rest never visited. It was also explained related that the majority of the Indonesian population had never watched cultural art shows/exhibitions in the last 3 (three) months, namely $70.2 \%$ of the population [2]. It can be concluded that the interest of the community in recognizing regional culture can still be said to be in a low category.

Starting from this, the current cultural diversity in Indonesia often becomes a problem and leads to radicalism in the community. This is proven that the level of character of Indonesian society is currently experiencing character degradation in several lines. Improving the quality of human resources is something that needs to be considered since early childhood. At an early age the brain develops 80 percent very quickly until the age of 8 years. Previous studies showed that children were born with 100 billion cells when they reach an early age, these connections develop up to several times the initial condition of 20,000 connections. The environment around the child, including 
the family, school, and the community, is very influential in this development. From this the researchers conclude that culture-based education that is instilled in children from an early age, will provide great opportunities for the development of the nation's noble cultural values. This research will focus on the introduction of Reyog Ponorogo main character, Prabu Klana Sewandana, to analyze the prototype form, symbolic meaning related to the values of the character of patriotism. In this research, the form of Prabu Klana Sewandana prototype is displayed in another form, namely Reyog Ponorogo Rod Puppet.

\section{METHOD}

The method used in this research included hermeneutic and heuristic methods. Hermeneutics itself is a qualitative type method for analyzing and facilitating textbooks, especially text comprehension. In this research, hermeneutics was used to express the meaning contained in the object of research in the form of the phenomenon of the story of the Bujang Ganong characters through understanding and interpretation.

Meanwhile, heuristic was used to develop a new model of the figure of Klana Sewandana through Wayang Golek and its relevance to the cultivation of the character of the motherland love. The primary data sources used in this research included the figures involved in the history of Reyog Ponorogo stories, in this case the administrators of Reyog Foundation, Ponorogo Regency. Furthermore, secondary data sources focused on the literacy study of Reyog Ponorogo stories and related source documentation.

\section{RESULTS AND DISCUSSION}

Reyog is one of the local arts originating from one of the East Java precisely in the City of Ponorogo. Ponorogo reyog art itself is known as a cultural art that has been established by UNESCO (United Nations Educational Scientific and Cultural Organization) as one of the original performing arts [3].

Reyog itself is a performance story as well as an original Ponorogo art that is full of valuable values. Starting from the historical story of Ponorogo reyog's emergence as one of the arts and shows that entertain the public, it turns out that there are different versions of the story. The first version of the story is the Bantarangin reyog story version and the one version of the Suromenggalan story. The difference in this version also makes the difference in the development of history books, the development of stories, and the functions of Ponorogo reyog characters and dances in the wider community. From the different versions in conveying Reyog Ponorogo's story, the researcher focused on the study of one of the main characters, namely Prabu Klana Sewandana [4].

The results of this study show two main things, in terms of the study through the hermeneutic method and the heuristic aspect. Examining the results from the heuristic point of view, the researchers produced a product development model of the Ponorogo reyog form on the Klana Sewandana figure through the Ponorogo reyog puppet form. In the results of this heuristic study, it was found that in the description of Klana Sewandana figures in the form of prototypes, Klana Sewandana masks are blood red, eyebrows show a blarak sinegar, Klana Sewandana's mouth shows a jambe sinegar, a long hair and njlaprang whiskers. The results of Ponorogo reyog puppet product in the Klana Sewandana figures are as follows:

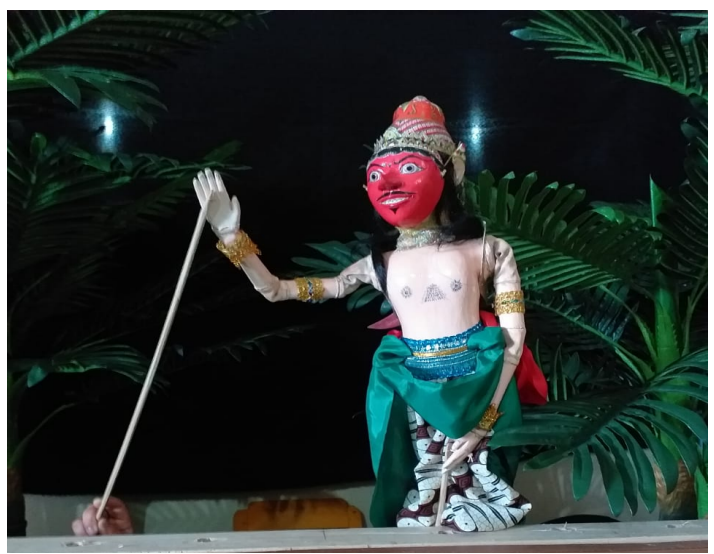

Figure 1 Wayang Golek Reyog Ponorogo Shape

Based on the results of the development of the Ponorogo reyog puppet show shows a special mask appears as a depiction of the figure of Klana Sewandana. The figure is said to be the central figure in the Reyog Ponorogo puppet. This Klana Sewandana figure is still a series in Javanese puppet characters in a series of Panji stories. Panji story featuring a feud between King Klana Sewandana and Raden Panji. The story shown shows a picture of a man who is in love with his ideal woman. Furthermore, in this Klana Sewandana character, a form of love is expressed towards Dewi Sekartaji or Dewi Songgolangit [5].

The depiction of the prototype mask Klana Sewandana is a blend of various colors, shapes that have their respective philosophies. This philosophy is a depiction of the character or character displayed by Klana Sewandana himself as a King and as a man who fights for love. Departing from the Panji story that depicts Klana Sewandana as a brave character. The depiction of the character is seen from the blood-red color and the shape of the bulging eyes [6].

The results of the joint study in the Focus Group Discussion (FGD) activity on 29 April 2019 with experts from the Reyog Ponorogo Foundation produced several philosophical insights on the Klana Sewandana mask. In this study seen in the Klana Sewandana mask can be seen from the shape of the eyebrows that show the sinegar blast, the shape of Klana Sewandana's mouth shows a short jambe sinegar, long unraveled hair, and a mustache njlaprang [7]. Furthermore, the results of hermeneutics in this study are focused on the literature review related to the story of the Klana Sewandana figure in the Ponorogo reyog story. In previous studies, there were three versions of stories about Reyog Ponorogo that were not given much attention by the public. The first version, it is said that Reyog Ponorogo tells Klana Sewandana as the king of Bantarangin who wants to propose to the daughter of Raja Kediri, Dewi Sanggalangit. In this version of the story, the conditions for applying for princesses are given by creating a new model of gamelan 
with a tiger-headed human, in the end the gamelan is known as the embryo of Reyog Ponorogo art. In the second version, tells of $\mathrm{Ki}$ Ageng Kutu leaving Majapahit, because Brawijaya $\mathrm{V}$ cannot master the work and is more controlled by his wife. Next Ki Ageng Kutu founded the Surukubeng hermitage to train young people to learn kanuragan through barongan games. It was said that this barongan was a form of satire against the leadership of King Brawijaya V. Finally, the King of Brawijaya sent Raden Katong to conquer Surukubeng and succeeded so that Raden Katong was entrusted with the Wengker fief land. Furthermore, the third version is that after Raden Katong defeated Ki Ageng Kutu, then Raden Katong preserved barongan as an Islamic propaganda media, barongan which once owned by Warok now belongs to the community by the name of Reyog [4]. In another study, the deputy chairman of the Ponorogo reyog foundation Pristiwanto said that there were fundamental differences in the two versions of the Ponorogo reyog story itself. The Bantarangin version describes the Reyog story as one of the stories that lead to the description of Klana Sewandana's Prabhu struggle, depicted in the love story to Dewi Sanggalangit. The next version is different, the Suromenggalan version that Ponorogo reyog story is a satirical picture (criticism) which was sparked to criticize Brawijaya's Prabu from Majapahit during his leadership [7].

The results of the literature review were strengthened by the results of the interview in the Focus Group Discussion (FGD) activity on 29 April 2019. The results of the first study can be seen that the symbolic meaning of the bloodred colour in the colour of the Klana Sewandana mask shows a brave character, firm and nurturing the community. Furthermore, Klana's Sewandana eyebrows shows a blarak sinegar which illustrates the character of a strong leader even though it seems antagonistic. The colour combination in the Klana Sewandana mask shows the harmony of the soul.

Understanding related to the character of the love of the motherland itself can be directed at the breakdown of cultural love in the motherland. There are several things that can be done in developing an attitude of love for the motherland itself, including 1) Appreciating the services of national figures/heroes; 2) Willing to use domestic products; 3) Appreciate the natural beauty and culture of Indonesia; 4) Choose to travel within the country [3].

In this research study, the portrayal of Klana Sewandana figures in historical studies through prototypes and in the study of the story is directed at the goal of planting the character of the love of the motherland that is valuing the services of the figures. This is focused on the introduction of local characters who are still very strong in Ponorogo, Prabu Klana Sewandana.

Related to the description of Klana Sewandana figures to strengthening the character of patriotism through the literature review and interview results, several aspects can be seen. The figure of the Klana Sewandana figure shows a wise, assertive and caring leader of the community as a picture of a leader that should be emulated by the community. In this study, it can be concluded that there is a Klana Sewandana character pattern that can be used as a reference for the development of the character of patriotism. The Ministry of National Education in the study conducted by Sari explained that the concept of patriotism is a way of thinking, behaving, and doing to be able to show loyalty, care and respect for the nation, the physical environment, social, cultural, economic or national politics. Referring to this figure Klana Sewandana which shows a leader or king who is wise and wise as a form of concern for the nation to prosper the community.

The figure of Klana Sewandana as a leader or king has a strong character in protecting the people under his leadership. Although in the story that is displayed from several versions of the story is more directed to the story of love and struggle of the King in obtaining Dewi Songgolangit, behind it implies how the ability of Klana Sewandana in maintaining integrity and responsibility in leading the Kingdom together with the Bujang Ganong governor. In the analysis conducted, the ability to maintain integrity is shown in the loyalty of the Bujang Ganong governor who can sacrifice himself in realizing the mission of the King. This shows that the King or Klana Sewandana can build the principle of loyalty and love for the country by respecting leaders and having a fighting spirit in achieving something.

\section{CONCLUSION}

The conclusion shows three main study points are as follows: a) In the study of prototypes of Klana Sewandana figures in the form of puppet show Reyog Ponorogo, Klana Sewandana mask is blood red; eyebrows show a blarak sinegar, Klana Sewandana's mouth shows a blarak sinegar with a cord, long loose hair, and njlaprang moustache; b) The symbolic meaning of the blood-red colour shows a brave character, firm and protective of society. Klana Sewandana's eyebrows show a blarak sinegar that illustrates the character of a firm leader despite being antagonistic. The combination of colours in the Klana Sewandana mask shows the harmony of the soul; c) The figure of the Klana Sewandana figure shows a leader who is wise, wise, assertive and protects the community as a picture of a leader that should be emulated by the community

\section{REFERENCES}

[1] U. N. Malang, B. Y. Wulansari, P. S. Utami, and U. M. Ponorogo, "Wayang Golek Reyog Ponorogo: The Acculturation of Indonesian Culture as Patriotism Character Education Learning," 2019.

[2] P. K. Pendidikan and K. R. Indonesia, "Analisis Kearifan Lokal Ditinjau dari Keragaman Budaya." Jakarta, 2016.

[3] A. Dj, Hubungan Kebudayaan Indonesia dan Malaysia : Sejarah dan Perkembangan Reyog Ponorogo ke Batu Pahat, Johor. 2014.

[4] A. Achmadi, “Aksiologi Reyog Ponorogo Relevansinya dengan Pembangunan Karakter Bangsa," J. Theol. Vol 25, No 1 Filsafat Islam. -

10.21580/teo.2014.25.1.336 . 
[5] R. M. Pramutomo, "Seni Pertunjukan Topeng

Tradisional di Surakarta dan Yogyakarta,” J. Kaji. Seni, vol. 1, no. 1, pp. 74-88, 2014.

[6] R. M. N. Purbacaraka, Z. Usman, and H. B. Jassin, Tjerita Pandji dalam perbandingan. Gunung Agung, 1968.

[7] S. Sulton, B. Y. Wulansari, and P. S. Utami, "Transformasi Cerita Tokoh Bujang Ganong Melalui Bentuk Dramatik Wayang Golek Reyog Ponorogo Sebagai Media Penanaman Karakter Cinta Tanah Air," in Seminar Nasional Pendidikan dan Pembelajaran 2019, 2019, pp. 451-459. 